\title{
The nutritional value of differently prepared barley in growing-finishing pigs *
}

\author{
M. Flis', W. Sobotka', K. Jakubowski², L. Mieszkalski ${ }^{3}$, \\ Z. Czarnyszewicz ${ }^{1}$ and A. Anders ${ }^{3}$
}

\author{
University of Warmia and Mazury \\ 10-718 Olsztyn. Poland \\ 'Institute of Animal Nutrition and Feed Management \\ Oczapowskiego 5 \\ ${ }^{2}$ Department of Pathophysiology \\ Oczapowskiego 13 \\ ${ }^{3}$ Institute of Agricultural Machinery and Equipment \\ Oczapowskicgo $/ 1$
}

(Received 18 July 2000; accepted 22 January 2001)

\section{ABSTRACT}

The nutritional value of diets containing differently prepared barley was determined in two experiments. Barley grain was prepared in the following ways: hammer milled to medium fine $(\mathrm{MH}$, $900 \mu \mathrm{m}$ ) or fine particles (FH, $600 \mu \mathrm{m})$, rolled (R), fine milled and expanded (E). Experiment I was conducted on 36 barrows, $28-95 \mathrm{~kg} \mathrm{BW}$ (9 animals per treatment), fed individually using a ration system. Experiment 2 was carried out on 48 pigs ( 6 barrows and 6 gifts per treatment), 30-100 kg $\mathrm{BW}$, maintained in groups and fed ad libitum. Daily weight gains, feed utilization and stomach lesions were determined in Experiments $\$$ and 2 . In Experiment 1, nutrient and energy digestibilities were also assayed.

It was found that the digestibility of protcin (by 3.3 units), fat and cnergy $(\mathrm{P}<0.05)$ were better in the $\mathrm{FH}$ than in the $\mathrm{MH}$ diet and that the $\mathrm{FH}$ diet, and contained about $0.5 \mathrm{MJ} / \mathrm{kg}$ more metabolizable energy. The digestibility of diet $R$ was also a slightly better $(P>0.05)$ and contained more metabolizable energy than $\mathrm{MH}$. The way of preparing barley had a greater effect on growth rate and feed utilization $(\mathrm{P}>0.05)$ in Experiment 2 in the pigs that were maintained in lots, fed ad libitum and gained about $900 \mathrm{~g}$ daily than in Experiment 1 in which pigs were fed rations according to standards and gained about $700 \mathrm{~g}$. For the faster growing pigs, rolled and expanded barley had a somewhat greater nutritional value (daily gains 937 and $936 \mathrm{~g}$ ), medium-fine milled barley had a lower value ( $865 \mathrm{~g}$ ).

* Supported by the Committee for Scientific Research, Grant No 5 P06E 057 
A greater frequency of oesophageal parakeratosis was found in pigs fed the diets containing tine milled and fine milled and expanded barley.

KEY WORDS: pigs, barley, milling, expanding, digestibility, growth performance, stomach

\section{INTRODUCTION}

Decreasing the particle size of feeds used in pig nutrition increases the surface area available to digestive enzymes in the gastrointestinal tract (Wondra et al., 1995a), nutrient digestibility and nutritional value (Wünsche et al., 1987; Wondra et al., 1995a,b). Appropriate particle size enhances growth performance. It was found that every $100 \mu \mathrm{m}$ reduction in the particle size of maize (from 1200 to $400 \mu \mathrm{m}$ ) increased the growth rate of pigs by $1.3 \%$ (Hancock et al., 1999). Taking into account the improved homogeneity of mixtures, digestibility, body weight gains, and feed utilization, it is recommended that grain should be milled to a moderate size of $600 \mu \mathrm{m}$ (Wondra et al., 1995a), and feed mixes to 400,500 and $700 \mu \mathrm{m}$ particles for piglets, fattening pigs and sows, respectively (Gendron, 1997, according to Royer, 1999). Fine milling, particularly using a hammer mill, consumes more electricity, leads to the formation of a large proportion of very fine particles (dust) and to an increase in the frequency of stomach disorders in pigs (Wondra et al., 1995a,b; Ayles et al., 1999). This is why various types of rollers are being used more frequently to mill grain. Our earlier studies (Flis et al., 2000) showed a highly significant decline in protein and fat digestibility in a diet containing rolled barley in comparison with the digestibility of these nutrients in a diet containing fine $(600 \mu \mathrm{m})$ milled barley, and even slightly worse digestibility in comparison with medium fine $(1000 \mu \mathrm{m})$ milled barley. The worse digestibility of rolled barley was attributed to the insufficient crushing of the grain used in this experiment. Laurinen et al. (2000) obtained different results in a study on the digestibility of protein and fat in mixtures containing barley rolled using three different types of rollers. Some types of rollers were so effective that the digestibility of the diets containing rolled barley was similar to that of diets with fine milled barley. Expanding is also used to increase the nutritional value of pig feed. Grain alone or feed mixtures containing grain are subjected to this process. In the studies of Vande Ginste and De Schrijver (1998) feeding pigs diets with a high proportion of expanded barley did not have a significant effect on weight gain, feed utilization, or on increasing intestinal and, total digestibility of protein and dry matter, and even had a negative influence on the digestibility of phosphorous and calcium.

The need to more effectively utilize feed nutrients, including grain, in feeding animals and the relative lack of information in the Polish literature on the effect of various methods of preparation of grains on their nutritive value in pig nutrition 
prompted us to undertake these experiments. The objective of this study was to determine the effect of the degree of milling, crushing or expanding of barley used in complete fecds for growing-finishing pigs on nutrient digestibility, growth performance and stomach health status.

\section{MATERIAL AND METHODS}

\section{Preparation of barley}

Barley cultivar Rodos was used in both experiments. Medium-fine $(\mathrm{MH})$ and fine $(\mathrm{FH})$ milling was carried out with hammer mill using 6 and $3 \mathrm{~mm}$ sieves, respectively. Barley was rolled $(R)$ using a machine with smooth rollers spaced $0.75 \mathrm{~mm}$, which ensured very good crushing of the grain. Fine milled barley ( $3 \mathrm{~mm}$ sieve) was expanded in an Amandus Kahl expander at $95-105^{\circ} \mathrm{C}$.

Particle-size distribution and the geometric mean particle size of barley prepared in various ways were determined in three replicates according to Polish Standards (PN 84/R-64798).

\section{Animals and diets}

Experiment 1. Four groups of Polish Large White $\mathrm{x}$ Duroc castrated males with an average initial body weight (BW) $28.4 \mathrm{~kg}$ were fed diets containing $\mathrm{MH}, \mathrm{FH}, \mathrm{R}$ and $\mathrm{E}$ barley and rapeseed- and soyabean meal as main protein sources (Table 1 ). The nutritive value of mixtures and feeding scale were applied according to the Nutrient Requirement of Pigs (1993). The pigs were housed in individual metabolic cages and fed on rations, $1.5-3.0 \mathrm{~kg}$ per day, moistend $1: 1$ with water, and given in two meals. The pigs had free access to automatic drinkers. Nutrient digestibility was determined twice on 5 barrows of each group: on pigs of $53 \mathrm{~kg} \mathrm{BW}$ fed on grower feed and on animals of $78 \mathrm{~kg}$ fed a finisher. Faeces were collected over 6 -day periods, samples of $20 \%$ were taken from daily collections and frozen. Dry matter, crude ash, ether extract, crude fibre, NDF, and energy were determined in samples dried in $60^{\circ} \mathrm{C}$, nitrogen in fresh defrosted samples. Digestibility coefficients and the equation developed by Hoffmann and Schiemann with the adjustments by Muller and Kirchgessner (Nutrient Requirement of Pigs, 1993) were used to calculate the metabolizable energy value of the feeds.

Experiment 2 was conducted at a commercial farm. Four groups of 6 Polish Landrace $\mathrm{x}$ Duroc $\mathrm{x}$ Hampshire barrows and 6 gilts with average initial weight $30 \mathrm{~kg}$ were housed in groups in pens with a concrete floor and rubber matting in one part. Each pen had one automatic feeder with an automatic nipple drinker. The pigs were fed diets containing barley prepared in the same way as in Experiment 1 . 
TABLE 1

Ingredients and composition of experimental grower and finisher feed mixtures $(\mathrm{g} / \mathrm{kg})$ in Experiments 1 and 2

\begin{tabular}{|c|c|c|c|c|}
\hline \multirow{3}{*}{ Item } & \multirow{2}{*}{\multicolumn{2}{|c|}{$\frac{\text { Growth and digestibility trials }}{\text { Experiment } \mathrm{I}}$}} & \multirow{2}{*}{\multicolumn{2}{|c|}{$\begin{array}{c}\text { Growth trials } \\
\text { Experiment } 2\end{array}$}} \\
\hline & & & & \\
\hline & Grower & Finisher & Grower & Finisher \\
\hline \multicolumn{5}{|l|}{ Ingredients } \\
\hline barley' & 741.8 & 805.7 & 746.8 & 812.8 \\
\hline soyabean meal & 100.0 & 50.0 & 110.0 & 60.0 \\
\hline rapeseed meal & 100.0 & 100.0 & 90.0 & 90.0 \\
\hline meat-and-bone meal & 35.0 & 20.0 & 35.0 & 20.0 \\
\hline dicalcium phosphate & 3.0 & 3.0 & 2.0 & 2.0 \\
\hline limestone & 8.0 & 9.0 & 4.0 & 3.0 \\
\hline salt & 4.0 & 4.0 & 3.0 & 3.0 \\
\hline L-lysine HCL $(78 \%)$ & 1.2 & 1.3 & 1.2 & 1.2 \\
\hline vitamin and mineral premix ${ }^{2}$ & 7.0 & 7.0 & 5.0 & 5.0 \\
\hline Agricid $^{3}$ & - & - & 3.0 & 3.0 \\
\hline \multicolumn{5}{|l|}{ Composition analyzed } \\
\hline dry matter & 874.5 & 876.1 & 879.3 & 872.2 \\
\hline crude ash & 47.0 & 40.8 & 47.7 & 42.0 \\
\hline crude protein & 173.9 & 149.6 & 167.9 & 149.5 \\
\hline ether extract & 23.5 & 21.5 & 22.1 & 24.2 \\
\hline crude fibre & 47.6 & 46.9 & 55.4 & 53.3 \\
\hline NDF - fibre & 174.9 & 184.4 & nd & nd \\
\hline gross energy, $\mathrm{MJ} / \mathrm{kg}$ & 16.26 & 16.18 & 16.40 & 16.69 \\
\hline \multicolumn{5}{|l|}{ Composition calculated $^{4}$} \\
\hline lysine & 9.0 & 7.5 & 9.0 & 7.5 \\
\hline methionine & 2.8 & 2.5 & 2.7 & 2.4 \\
\hline threonine & 6.2 & 5.4 & 6.2 & 5.8 \\
\hline $\mathrm{Ca}$ & 7.9 & 6.8 & 7.6 & 5.9 \\
\hline $\mathrm{P}$ & 6.4 & 5.7 & 6.1 & 5.5 \\
\hline $\mathrm{ME}, \mathrm{MJ} / \mathrm{kg}$ & 12.18 & 12.13 & 12.21 & 12.16 \\
\hline
\end{tabular}

1 barley were differently ground or processed; medium hammer milled = group MH; fine hammer milled $=$ group $\mathrm{FH}$; rolled $=$ group $\mathrm{R}$; fine hammer milled and expanded $=$ group $\mathrm{E}$

2 premix used in Experiment 1 were on wheat middlings carrier but in Experiment 2 on ground limestone carrier

3 preparation with lactic acid

${ }^{4}$ calculated according to Nutrient Requirement of Pigs. Nutritive Value of Feeds (1993) 
The composition and nutrient value of the feed mixtures are presented in Table 1. Ad libitum feeding was used throughout the experiment. Feed consumption was measured as the difference between the amount of feed put into the feeders and the estimated amount of scattered and left feed.

\section{Carcass and stomach evaluation}

At the end of experiments, the pigs were slaughtered in slaughterhouse. The hot carcass dressing percentage and meat percentage were determined according to the EUROP system using an FOM 100 ultrasonic apparatus.

Stomach health status was evaluated immediately after slaughter. The stomachs were cut open along the greater curvature, emptied and rinsed with water. The condition of the mucous membrane was determined macroscopically. A stomach score was assigned using a $0-4$ point scale: $0=$ normal, $1=$ slight parakeratosis, $2=$ moderately advanced parakeratosis, hyperaemia or petechia, $3=$ extensive parakeratosis, $4=$ ulcer.

\section{Chemical analysis}

The nutrient contents of feeds and faeces were determined by conventional methods (AOAC, 1990). The gross energy content in feed mixtures and faeces was determined by combustion in a calorimeter with an adiabatic bomb. The contents and gelatinization of starch in expanded barley were determined by the method of Tsuge et al. (1990).

\section{Statistical analysis}

Onc-way analysis of variance and the Duncan multiple range test were used to analyze the results of Experiment 1 (digestibility, daily gains, feed utilization, carcass dressing percentage, and meat percentage) and Experiment 2 (initial and final body weight, daily gains, carcass dressing percentage and meat percentage).

\section{RESULTS AND DISCUSSION}

Particle size

Medium-fine milled barley $(\mathrm{MH})$ had a considerable proportion of large (over $1020 \mu \mathrm{m})$ particles $(42-43 \%)$ and a small proportion of very fine particles $(<430 \mu \mathrm{m}$, $15-17 \%$ ) (Table 2). Fine milled barley (FH) contained few large particles (14$17 \%$ ) but also contain less very fine particles $(24-28 \%)$. The average size of barley 
TABLE 2

Particle size distribution (\% on weight basis), mean geometric particle size of ground barley and starch gelatinization of expanded barley (Experiments 1 and 2)

\begin{tabular}{|c|c|c|c|c|c|c|c|c|}
\hline \multirow[t]{2}{*}{ Particle size, $\mu \mathrm{m}$} & \multicolumn{4}{|c|}{ Experiment 1} & \multicolumn{4}{|c|}{ Experiment 2} \\
\hline & $\mathrm{MH}$ & $\mathrm{FH}$ & $\mathrm{R}$ & $E^{\prime}$ & $\mathrm{MH}$ & $\mathrm{FH}$ & $\mathrm{R}$ & $E^{\prime}$ \\
\hline $5000<$ & & & 2.5 & & & & 4.0 & \\
\hline $4000-5000$ & & & 11.8 & & & & 16.0 & \\
\hline $3000-4000$ & 2.3 & 0.8 & 17.1 & 0.1 & 3.9 & 0.4 & 23.0 & 0.1 \\
\hline $2000-3000$ & 3.9 & 0.5 & 18.5 & 1.0 & 3.5 & 0.4 & 11.7 & 0.3 \\
\hline $1500-2000$ & 20.6 & 4.4 & 24.6 & 5.4 & 21.5 & 6.4 & 23.3 & 5.0 \\
\hline $1020-1500$ & 15.2 & 8.7 & 7.6 & 8.2 & 14.2 & 9.9 & 7.7 & 8.8 \\
\hline $600-1020$ & 36.4 & 49.4 & 10.0 & 47.8 & 36.8 & 50.1 & 8.8 & 48.6 \\
\hline $430-600$ & 4.3 & 8.3 & 1.3 & 8.1 & 5.0 & 8.8 & 1.0 & 10.1 \\
\hline $250-430$ & 9.2 & 15.4 & 2.9 & 15.4 & 8.6 & 14.0 & 1.9 & 15.3 \\
\hline$<250$ & 8.1 & 12.5 & 3.7 & 14.0 & 6.5 & 10.0 & 2.6 & 11.8 \\
\hline $\begin{array}{l}\text { Mean geometric } \\
\text { particle size, } \mu \mathrm{m}\end{array}$ & 929 & 610 & 1940 & 596 & 920 & 648 & 2120 & 606 \\
\hline Starch content, \% & & & & 63.0 & & & & 60.8 \\
\hline $\begin{array}{l}\text { Starch gelatinization } \\
\text { after expanding, } \%\end{array}$ & & & & 37.0 & & & & 46.8 \\
\hline
\end{tabular}

' before expanding

particles in MH was 929 and $920 \mu \mathrm{m}$ in Experiments 1 and 2, respectively. Milled grain that is less homogenous in terms of particle size is often used in feed mixtures for pigs (Ślaska-Grzywna, 1981). The average particle size of $\mathrm{FH}$ fine milled barley was 610 and $648 \mu \mathrm{m}$. Gendron (1997, according to Royer, 1999) recommends even finer milling of feeds for growing pigs, to $500 \mu \mathrm{m}$. Rolled barley had a wider range of particle size than milled grain and a large average particle size $(1940$ and $2120 \mu \mathrm{m})$. Sieve analysis of rolled grains does not give a good idea about how well the grain is cracked. Even very well rolled grain has large particles between 2000 to $4000 \mu \mathrm{m}$ in size, especially rolled barley, which contains hulls that have not been crushed.

The technical difficulties in expanding barley have been described by Laurinen et al. (1998). The degree of gelatinization of starch was $37 \%$ in Experiment 1 and $46.8 \%$ in Experiment 2.

\section{Digestibility of diets}

Fine milled (FH) barley was better digested than medium-fine milled (MH). In grower diets crude protein, gross energy and ether extract digestibility of $\mathrm{FH}$, containing fine milled barley, were better than in the $\mathrm{MH}$ diet containing medium-fine 
milled grain (3.4, and 2.7, $\mathrm{P}<0.05$ and 25.8, $\mathrm{P}<0.01$ units, respectively; Table 3 ). In the finisher FH diet, only crude protein and ether extract digestibility were greater than in the $\mathrm{MH}$ diet $(\mathrm{P}<0.05)$. Similarly as in our experiment, Wünsche et al. (1987) and Wondra et al. (1995a) found that increasing the fineness of milled grain increases digestibility. This relationship was not found in the studies of Laurinen et al. (2000), in which the digestibility of grain milled fine and very fine was determined.

Taking into account its effect on digestibility, rolling barley was a somewhat less effective method of grinding than fine milling, but slightly more effective than medium-fine milling. The protein and energy of grower and finisher $\mathrm{R}$ diets were digested slightly better $(\mathrm{P}>0.05)$ and the ether extract was significantly better $(\mathrm{P}<0.05)$ than in diet $\mathrm{MH}$.

Expanding fine milled barley lowered the digestibility of crude protein, $72.1 \mathrm{vs}$ $76.8 \%$ in the grower $\operatorname{diet}(\mathrm{P}<0.01)$ and 75.3 vs $78.8 \%$ in the finisher $\operatorname{diet}(\mathrm{P}<0.05)$. The digestibility of other components of diet $\mathrm{E}$, containing expanded barley, was similar to that in the FH diet containing fine milled barley. Despite the considera-

TABLE 3 Digestibility of the feeds mixtures (\%) containing differently ground or expanded barley (Experiment 1)

\begin{tabular}{|c|c|c|c|c|c|}
\hline \multirow{2}{*}{ Item } & \multicolumn{4}{|c|}{ Feed mixtures } & \multirow{2}{*}{ SE } \\
\hline & $\mathrm{MH}$ & $\mathrm{FH}$ & $\mathrm{R}$ & $\mathrm{E}$ & \\
\hline Grower diets, & 5 & 5 & 5 & 4 & \\
\hline crude protein & $73.4^{\mathrm{bc}}$ & $76.8^{\mathrm{a} \wedge}$ & $75.6^{\mathrm{ib}}$ & $72.1^{\mathrm{cl3}}$ & 0.41 \\
\hline ether extract & $30.3^{B}$ & $56.1^{A}$ & $60.8^{\mathrm{A}}$ & $58.1^{\mathrm{A}}$ & 1.42 \\
\hline crude fibre & 31.1 & 33.1 & 28.8 & 31.9 & 0.51 \\
\hline NDF & 56.8 & 57.4 & 57.0 & 58.3 & 0.49 \\
\hline $\mathrm{N}$-free extractives & 88.0 & 89.2 & 88.9 & 88.4 & 0.16 \\
\hline gross energy, $\mathrm{MJ} / \mathrm{kg}$ & $77.6^{6}$ & $80.3^{a}$ & $79.6^{\mathrm{ub}}$ & $78.8^{\mathrm{ah}}$ & 0.26 \\
\hline $\mathrm{ME}, \mathrm{MJ} / \mathrm{kg}^{1}$ & 11.93 & 12.43 & 12.35 & 12.15 & \\
\hline Finisher diets, & 5 & 5 & 5 & 5 & \\
\hline crude protcin & $75.5^{\mathrm{b}}$ & $78.8^{\mathrm{a}}$ & $77.3^{\mathrm{ab}}$ & $75.3^{b}$ & 0.31 \\
\hline ether extract & $45.3^{\mathrm{b}}$ & $67.2^{\mathrm{a}}$ & $64.7^{\mathrm{a}}$ & $64.3^{a}$ & 1.68 \\
\hline crude fibre & 29.1 & 30.6 & 30.0 & 32.7 & 0.70 \\
\hline NDF & 58.6 & 59.4 & 59.1 & 60.1 & 0.36 \\
\hline $\mathrm{N}$-free extractives & 88.2 & 89.7 & 89.6 & 89.2 & 0.18 \\
\hline gross energy, $\mathrm{MJ} / \mathrm{kg}$ & 78.8 & 81.2 & 80.8 & 79.8 & 0.25 \\
\hline $\mathrm{ME}, \mathrm{MJ} / \mathrm{kg}^{\mathrm{l}}$ & 12.24 & 12.70 & 12.62 & 12.52 & \\
\hline
\end{tabular}

SE standard error of mean

1 calculated from digestible nutrients

a.b,c $-\mathrm{P} \leq 0.05$; $^{\mathrm{A} . \mathrm{B}}-\mathrm{P} \leq 0.01$ 
ble degree of gelatinization of starch in expanded barley $(37 \%)$, the digestibility of $\mathrm{N}$-free extractives and energy of diet $\mathrm{E}$ did not increase. The digestibility results obtained in this study are similar to the values obtained in earlier experiments. A tendency towards decreasing digestibility of components of diets containing expanded barley was found in the studies of Laurinen et al. (1998). A similar trend towards decreased digestibility of expanded diets containing a large proportion of barley was observed in the studies of Vande Ginste and De Schrijver (1998). The lack of a favourable effect of expanding barley on digestibility may result from greater digesta viscosity caused by the increased content of soluble nonstarch polysaccharides (NSP) resulting from expanding. Edwards (1999) explains the lack of a positive effect of expanding on the nutritive value of some diets in pig nutrition by the rise in the proportion of soluble NSP and deactivation of feed enzymes.

The amount of metabolizable energy in the diets calculated from the content of digestible components differed. The FH diets had higher energy contents ( 12.43 and $12.70 \mathrm{MJ} / \mathrm{kg}$, for grower and finisher, respectively), the $\mathrm{MH}$ diets had the least (11.93 and $12.24 \mathrm{MJ} / \mathrm{kg}$ ). The difference in the metabolizable energy content between the $\mathrm{FH}$ and $\mathrm{MH}$ diets was the largest and equaled about $0.5 \mathrm{MJ} / \mathrm{kg}$.

\section{Growth performance}

The methods of preparing barley for inclusion in the diets did not have a significant effect on daily weight gains of pigs in Experiment 1, which throughout the experimental period (28-95 kg BW) gained 706-732 $\mathrm{g}$ (Table 4). The animals fed diet R, with rolled barley, grew somewhat better (by about $3 \%$ ) than those fed medium-fine milled or expanded barley. Feed utilization throughout the experiment equaled $3.16-3.22 \mathrm{~kg} / \mathrm{kg}$ and did not differ significantly. Pigs fed the rolled barley (R) diet consumed less feed by $0.12-0.16 \mathrm{~kg} / \mathrm{kg}$, i.e., by $4-5 \%$, in comparison with other groups.

The hot carcass dressing percentage was similar (77.9-78.8\%). The meat percentage of the carcasses of groups $\mathrm{MH}, \mathrm{FH}$ and $\mathrm{E}$ was smaller (47.9-49.8\%), and in group $\mathrm{R}$ greater $(52.0 \%)$, but the differences were not significant.

In Experiment 2, average daily intake of diet FH containing fine milled barley, was slightly lower in the growing, finishing and entire period of fattening than of the diets containing medium-fine milled, rolled, or expanded barley, $\mathrm{MH}, \mathrm{R}, \mathrm{E}$, respectively (Table 5). The rolled barley diet $(R)$ was consumed in smaller amounts only in the growing period. Smaller daily consumption of fine milled diets $(400 \mu \mathrm{m})$ than medium-fine milled diets $(800 \mu \mathrm{m})$ was also seen in the study by Wondra et al. (1995b), on growing pigs from 55 to $113 \mathrm{~kg} \mathrm{BW}$.

In the first period of growth (30-70 kg BW), no significant differences were found in the daily gains of pigs fed dicts containing differently prepared barley. 
TABLE 4

Growth performance (Experiment !)

\begin{tabular}{|c|c|c|c|c|c|}
\hline \multirow{2}{*}{ Item } & \multicolumn{4}{|c|}{ Group } & \multirow{2}{*}{ SE } \\
\hline & $\mathrm{MH}$ & $\mathrm{FH}$ & $\mathrm{R}$ & $\mathrm{E}$ & \\
\hline Number of animals & 9 & 9 & 9 & 9 & \\
\hline Initial body weight, $\mathrm{kg}$ & 28.5 & 29.0 & 27.6 & 28.7 & 0.83 \\
\hline Final body weight, kg & 95.6 & 95.9 & 95.1 & 95.4 & 0.69 \\
\hline Feeding period, days & 94.6 & 93.7 & 92.4 & 94.6 & \\
\hline Daily feed intake (28-95 kg BW), $\mathrm{kg}$ & 2.34 & 2.34 & 2.29 & 2.31 & 0.01 \\
\hline \multicolumn{6}{|l|}{ Daily weight gain, g } \\
\hline $28-63 \mathrm{~kg}$ & 721 & 686 & 722 & 655 & 10.08 \\
\hline $63.95 \mathrm{~kg}$ & 701 & 755 & 750 & 757 & 16.81 \\
\hline $28-95 \mathrm{~kg}$ & 710 & 716 & 732 & 706 & 10.50 \\
\hline \multicolumn{6}{|l|}{ Feed conversion ratio, $\mathrm{kg} / \mathrm{kg}$} \\
\hline $28-63 \mathrm{~kg}$ & 2.71 & 2.85 & 2.69 & 2.99 & 0.04 \\
\hline $63-95 \mathrm{~kg}$ & 4.08 & 3.76 & 3.71 & 3.60 & 0.09 \\
\hline $28-95 \mathrm{~kg}$ & 3.32 & 3.30 & 3.16 & 3.28 & 0.05 \\
\hline Dressing percentage & 78.2 & 78.1 & 77.9 & 78.8 & 0.22 \\
\hline Meatness of carcasses, $\%$ & 49.8 & 47.9 & 52.0 & 49.6 & 0.74 \\
\hline Stomach morfology, & 8 & 8 & 9 & 9 & \\
\hline normal & 3 & 1 & 3 & 2 & \\
\hline parakeratosis mild & 0 & 0 & 1 & 0 & \\
\hline parakeratosis moderate & 1 & 3 & 0 & 3 & \\
\hline parakeratosis severe & 0 & 0 & 0 & 0 & \\
\hline ulcers & 0 & 0 & 0 & 0 & \\
\hline hyperacmia and petcchia & 6 & 8 & 6 & 7 & \\
\hline stomach score & 1.75 & 2.75 & 1.44 & 2.22 & \\
\hline
\end{tabular}

Pigs in group $\mathrm{MH}$ had smaller gains, particularly in comparison with the groups fed rolled and expanded barley ( $885 \mathrm{~g}$ vs 922 and $918 \mathrm{~g}$, respectively). In the final period of fattening (70-100 kg BW), differences in growth rates were more pronounced. Pigs fed the diets with rolled (R) and expanded (E) barley grew best, the poorest growth was in pigs receiving the medium-fine milled diet, $\mathrm{MH}(\mathrm{P}<0.01)$. During the entire period of fattening, daily weight gains did not differ significantly, but in groups $\mathrm{R}$ and $\mathrm{E}$ they were $8 \%$ higher than in $\mathrm{MH}(\mathrm{P}=0.13)$ and $3.8 \%$ greater than in group $\mathrm{FH}$.

The considerable, $\sim 200 \mathrm{~g}$, difference in the daily weight gain of pigs in Experiments 1 and 2 is difficult to explain. In part it may have resulted from the different 
TABLE 5

Growth performance (Experiment 2)

\begin{tabular}{|c|c|c|c|c|c|}
\hline \multirow{2}{*}{ Item } & \multicolumn{4}{|c|}{ Group } & \multirow{2}{*}{ SE } \\
\hline & $\mathrm{MH}$ & $\mathrm{FH}$ & $\mathrm{R}$ & $\mathrm{E}$ & \\
\hline Number of animals & 12 & 12 & 12 & 12 & \\
\hline Initial body weight, $\mathrm{kg}$ & 29.8 & 30.2 & 30.1 & 29.8 & 0.23 \\
\hline Final body weight, kg & 98.4 & 99.3 & 101.1 & 101.0 & 0.66 \\
\hline Feeding period, days & 79.6 & 77.0 & 76.0 & 76.3 & \\
\hline \multicolumn{6}{|l|}{ Daily feed intake, $\mathrm{kg}$} \\
\hline $30-70 \mathrm{~kg}$ & 2.64 & 2.48 & 2.45 & 2.61 & \\
\hline $70-100 \mathrm{~kg}$ & 3.26 & 3.14 & 3.48 & 3.33 & \\
\hline $30-100 \mathrm{~kg}$ & 2.89 & 2.77 & 2.90 & 2.92 & \\
\hline 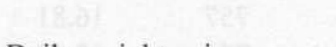 & & & & & \\
\hline \multicolumn{6}{|l|}{ Daily weight gain, $g$} \\
\hline $30-70 \mathrm{~kg}$ & 885 & 906 & 922 & 918 & 13.43 \\
\hline $70-100 \mathrm{~kg}$ & $825^{\mathrm{B}}$ & $891^{\mathrm{AB}}$ & $956^{\mathrm{A}}$ & $965^{\wedge}$ & 15.91 \\
\hline $30-100 \mathrm{~kg}$ & 865 & 898 & 937 & 936 & 11.26 \\
\hline \multicolumn{6}{|l|}{ Feed conversion ratio, $\mathrm{kg} / \mathrm{kg}$} \\
\hline $30-70 \mathrm{~kg}$ & 2.98 & 2.74 & 2.66 & 2.85 & \\
\hline $70-100 \mathrm{~kg}$ & 3.94 & 3.55 & 3.67 & 3.49 & \\
\hline $30-100 \mathrm{~kg}$ & 3.35 & 3.09 & 3.10 & 3.13 & \\
\hline Dressing percentage & 76.0 & 77.4 & 75.8 & 76.5 & 0.38 \\
\hline Meatness of carcasses, $\%$ & 49.4 & 49.7 & 49.3 & 49.9 & 0.69 \\
\hline \multirow{5}{*}{$\begin{array}{l}\text { Stomach morfology, } \\
\text { normal } \\
\text { parakeratosis mild } \\
\text { parakeratosis moderate } \\
\text { parakeratosis severe }\end{array}$} & 10 & 11 & 11 & 11 & \\
\hline & 2 & 2 & 4 & 1 & \\
\hline & 2 & 1 & 0 & 8 & \\
\hline & 0 & 0 & 1 & 0 & \\
\hline & 0 & 0 & 0 & 0 & \\
\hline ulcers & 0 & 1 & 0 & 0 & \\
\hline hyperaemia and petechia & 8 & 10 & 6 & 5 & \\
\hline stomach score & 1.80 & 2.27 & 1.27 & 1.63 & \\
\hline
\end{tabular}

$\mathrm{A}, \mathrm{B}-\mathrm{P} \leq 0.01$

feeding systems used and consequent differences in the average daily feed intake ( $2.32 \mathrm{~kg}$ in Experiment 1 and $2.85 \mathrm{~kg}$ in Experiment 2 ) and in part by the slightly different genotypes of the animals in the two experiments.

In Experiment 2 feed utilization was better in animals fed the fine milled, rolled, and expanded barley $(3.09-3.13 \mathrm{~kg} / \mathrm{kg}$ ) and worse in pigs given diets containing medium-fine milled barley $(3.35 \mathrm{~kg} / \mathrm{kg})$. 
Hot carcass dressing percentage did not differ significantly, but was slightly higher in the group fed fine milled barley (77.4\%) and smaller in pigs receiving the rolled barley diet $(75.8 \%)$. The carcass meat percentage ranged from 49.3 to $49.9 \%$.

The methods used to prepare the barley fed in rapeseed-soyabean diets had varied effects on the growth performance of pigs. In Experiment 1 the pigs were fed using a ration system and gained about $700 \mathrm{~g}$ daily. These pigs were practically did not responded to the forms of barley that differed in terms of digestibility and metabolizable energy contents. In Experiment 2 pigs were fed ad libitum, consumed more feed and gained more, $900 \mathrm{~g}$ daily. The manner of preparing barley had a greater effect on the analyzed parameters. Diets containing rolled, expanded and fine milled barley were more effective than the medium-fine milled diets. On average, during fattening, $0.30 \mathrm{~kg}$ body weight gain was obtained from $1 \mathrm{~kg}$ of $\mathrm{MH}$ diet and $0.32 \mathrm{~kg}$ from diets FH, R and $\mathrm{E}$. The results of both experiments show that in barley-rapeseed-soyabean diets that are balanced in terms of protein, increasing the energy value by the appropriate grinding or expanding of barley has a beneficial effect on daily weight gain only in pigs with greater growth rates. Earlier studies (Chabiera et al., 1994; Urbańczyk, 1998) have also shown that the growth rate of pigs increases when the energy concentration increases in diets balanced in terms of protein quantity and quality.

\section{Stomach morphology}

The condition of the stomachs of pigs in both experiments was good (Tables 4 and 5). With only one exception, no ulcers were found. In pigs fed expanded and fine milled barley, a higher frequency of parakeratosis in the pars oesophagea was found, but only in a slight or moderately advanced degree. Wondra et al. (1995a) found greater unfavourable changes in pig stomachs than in our study. Decreasing the particle size of maize in the diets of pigs $(55-114 \mathrm{~kg} \mathrm{BW})$ from 1000 to $600 \mu \mathrm{m}$ caused the ulceration index of the pars oesophagea to risc from 1.1 to 1.5 and the keratinization index, from 1.4 to 2.5 . In these studies the least unfavourable changes, including hyperaemia and petechia, were found in pigs fed rolled barley. The reasons for the greater frequency of stomach disorders in pigs fed fine milled feeds are not well understood. In the studies of Regina et al. (1999) a lower dry matter content was found in the stomach contents of pigs fed fine milled diets $(600 \mu \mathrm{m})$ than coarse-milled $(900 \mu \mathrm{m})$ ones. According to the cited authors, the lower dry matter content and greater liquidity of the stomach contents together with the hydrochloric acid and pepsin secreted by the stomach may play a significant role in initiating pathologic lesions. 


\section{CONCLUSIONS}

Among the four evaluated diets containing barley prepared by various methods $(\mathrm{MH}, \mathrm{FH}, \mathrm{R}, \mathrm{E})$ the greatest nutrients digestibility and metabolizable energy content were found in diet FH with fine milled barley $(600 \mu \mathrm{m})$, the lowest in diet $\mathrm{MH}$ with medium-fine milled barley $(900 \mu \mathrm{m})$.

The way of preparing the barley had a greater effect on the daily weight gains of pigs fed ad libitum that were gaining about $900 \mathrm{~g}$ daily (Experiment 2) than on those fed in accordance with standards and gaining about $700 \mathrm{~g}$ daily (Experiment 1). For pigs with higher growth rates, rolled barley and expanded barley (fine milled first) had a slightly greater value, fine milled barley, a moderate one, and medium-fine milled, the lowest. In pigs fed expanded grain or fine milled barley parakeratosis of the stomach was, however, more frequent.

\section{REFERENCES}

AOAC, 1990. Official Methods of Analysis. $15^{\text {th }}$ Edition. Association of Official Analytical Chemists. Washington, DC

Ayles H.L., Friendship R.M., Bubenik G.A., Ball R.O., 1999. Effect of feed particle size and dietary melaton supplementation on gastric ulcers in swine. Can J. Anim. Sci. 79, 179-185

Chabiera K., Kotarbińska M., Raj S., Fandrejewski H., Weremko D., 1994. Effect of intake of metabolizable energy and lysine on the performance and chemical body composition of growing pigs (in Polish). In: Proceedings of $1^{\text {st }}$ Conference In: ,Recent Advances in Swine Nutrition”, Jabłonna (Poland), pp. 38-41

Edwards A.C., 1999. Feed processing and feeding management to enhance nutrient utilization in commercial livestock production. Rec. Advan. Anim. Nutr., Australia 12, 137-144

Flis M., Sobotka W., Mieszkalski L., Mańkowski S., 2000. Digestibility and growth performance of growing-finishing pigs fed diets with differently ground or expanded barley. Czech J. Anim. Sci. $45,451-455$

Hancock J.D., Wondra K.J., Taylor S.L., Mavromichalis I., 1999. Strategies to improve growth performance and decrease cost of gain in pigs. Feed Mix 7 (4), 18-21

Laurinen P., Valaja J., Näsi M., Smeds K., 1998. Effects of different expander processing conditions on the nutritive value of barley and wheat by-products in pig diets. Anim. Feed Sci. Tech. 74, 213-227

Laurinen P., Siljander-Rasi H., Karhumen J., Alaviuhkola T., Näsi M., Tuppi K., 2000. Effects of different grinding methods and particle size of barley and wheat on pig performance and digestibility. Anim. Feed Sci. Tech. 83, 1-16

Nutrient Requirement of Pigs. Nutritive Value of Feeds (in Polish), 1993. The Kielanowski Institute of Animal Physiology and Nutrition (Editor). Jabłonna (Poland)

PN-84/R-64798. Feed. Determination of Granulation (in Polish)

Regina D.C., Eisemann J.H., Lang J.A., Argenzio R.A., 1999. Changes in gastric contents in pig fed a finely ground and pelleted or coarsely ground meal diet. J. Anim. Sci. 77, 2721-2729

Royer E., 1999. La granulometrie des aliments porcins fabriques á la ferme. Techn. Porc. 2 (4), 29-32 
Ślaska-Grzywna B., 1981. Study on basic indicators run quality of grinders in small feed mills (in Polish). Biul. inf. Przem. Pasz. 4, 26-35

Tsuge H., Hishida M., Iwasaki H., Watanabe S., 1990. Enzymatic evaluation for the degree of starch retrogradation in foods and feedstuffs. Starch 42, 213-216

Urbańczyk J., 1998. Effects of feeding intensity and dietary energy and amino acid concentration of fattening and slaughter results of pigs high in lean (in Polish). Rocz. Nauk. Zoot., Rozprawy habil. No 8, pp. 1-62

Vande Ginste J., De Shrijver R., 1998. Expansion and pelleting of starter, grower and finisher diets for pigs: effects on nitrogen retention, ileal and total tract digestibility of protein, phosphorus and calcium and in vitro protein quality. Anim. Feed Sci. Tech. 72, 303-314

Wondra K.J., Hancock J.D., Behnke K.C., Hines R.H., Stark C.R., 1995a. Effects of particle size and pelleting on growth performance, nutrient digestibility, and stomach morphology in finishing pigs. J. Anim. Sci. 73, 757-763

Wondra K.J., Hancock J.D., Behnke K.C., Stark C.R., 1995b. Effects of mill type and particle size uniformity on growth performance, nutrient digestibility, and stomach morphology in finishing pigs. J. Anim. Sci. 73, 2564-2573

Wünsche J., Herrmann U., Meinl M., Hennig U., Kreienbring F., Zwierz P., 1987. Einfluß exogener Faktoren auf die präzäkale Nährstoff und Aminosäurenresorption, ermittelt an Schweinen mit Ileo-Rektal-Analstomosen. Arch. Anim. Nutr. 37, 745-764

\section{STRESZCZENIE}

\section{Wartość pokarmowa różnie przyrządzonego ziarna jęczmienia w żywieniu tuczników}

W dwóch doświadczeniach określono wartość pokarmową mieszanek paszowych z udziałem różnie przyrządzonego jęczmienia. Doświadczenie 1 przeprowadzono na 36 wieprzkach (28-95 kg m.c.) żywionych indywidualnie systemem dawkowanym, a doświadczenie 2 na 48 świniach (24 wieprzki i 24 loszki), 30-100 kg m.c., żywionych grupowo, do woli. Zastosowano cztery mieszanki z udziałem jęczmienia: MH-ześrutowanego średnio miałko $(900 \mu \mathrm{m})$, FH-ześrutowanego miałko $(600 \mu \mathrm{m})$, R-gniecionego, E-ześrutowanego miałko i ekspandowanego. Oznaczono przyrosty dzienne, wykorzystanie paszy i stan zdrowotny żołądków (doświadczenia 1 i 2) oraz strawność składników pokarmowych i energii mieszanek paszowych (doświadczenie 1).

Stwierdzono, że strawność białka (o 3,3 jednostek), tłuszczu i energii $(\mathrm{P}<0.05)$ mieszanek paszowych FH była lepsza niż mieszanek $\mathrm{MH}$; zawierały one o około $0.5 \mathrm{MJ} / \mathrm{kg}$ więcej energii metabolicznej. Strawność mieszanki R była także trochę lepsza ( $\mathrm{P}>0.05)$, a zawartość energii metabolicznej była większa niż $\mathrm{MH}$. Sposób przyrządzenia jęczmienia miał większy wpływ na tempo wzrostu i wykorzystanie paszy $(\mathrm{P}>0.05)$ w doświadczeniu 2 , u świń utrzymywanych grupowo, żywionych do woli i przyrastających po około $900 \mathrm{~g}$ dziennie niż w doświadczeniu 1 , u świń żywionych według norm i przyrastających po około $700 \mathrm{~g}$. Dla szybciej rosnących świń trochę większą wartość odżywczą miał jęczmień gnieciony i ekspandowany (przyrosty dobowe 937 i 936 g), a mniejszą ześrutowany średnio miałko (przyrosty $865 \mathrm{~g}$ ). Większą częstotliwość występowania parakeratozy przełykowej części żołądka stwierdzono u świń żywionych mieszankami z jęczmieniem ześrutowanym miałko (FH) oraz ześrutowanym miałko i ekspandowanym (E) niż u pozostałych. 